\title{
The inhibitory effect of aqueous and alcoholic extract of red pepper on some isolated pathogenic bacteria from different areas of human body
}

Lina Qays Yaseen ${ }^{1}$, Sura Hameed Nayyef ${ }^{2}$ \& Nadia Ibraheem Salih ${ }^{3}$

DOI. 10.21931/RB/2021.06.04.21

Abstract: In most underdeveloped nations, traditional medicine, including herbal treatment, is still widely used. Due to the growth of antibiotic resistance, this study aims to use pepper as an anti-bacterial as alternative to antibiotics. Pepper is one of the most important plants used as a medicine for a long time in various countries and civilizations. This study aims to use pepper as an anti-bacterial in alternative to antibiotics. The current study included the inhibitory efficacy of aqueous and alcoholic red pepper extract on seven bacterial isolates: Staphylococcus aureus, Streptococcus spp, Escherichia coli, Klebseilla spp, Salmonella spp, Pseudomonas aeruginosa, Proteus spp. These isolates were isolated from different pathologies and regions, and they were diagnosed according to the site of infection. Several antibiotics were also used as a standard control sample for germs. This study shows that the highest inhibitory Effect against E. coli bacterium, as the average inhibition diameter was about $16.5 \mathrm{~mm}$, and it is an excellent inhibitory when compared to the antagonist's gentamicin and nitrofurantoin as it showed good inhibitory efficacy against the bacteria such as S. aureus, P. aeruginosa, and Salmonella spp. While the effect on Klebsiella was equal, on the other hand, the aqueous extract did not show any efficacy against Proteus spp, as was shown in the results. The results also showed that Staph. Aureus bacteria were the most affected by the alcohol extract of the red pepper as it showed a high inhibition zone compared with the control sample tetracycline and nitrofurantoin. The plant's aqueous and alcoholic red pepper extracts were effective against the tested bacterial isolates. The plant's aqueous and alcoholic red pepper extract has good inhibitory efficacy against the studied bacterial isolates.

Key words: Red Pepper Alcoholic extract, Aqueous extract, antagonism, Inhibition activity.

\section{Introduction}

Traditional medicine, including herbal medicine, is still widely practiced in most developing countries. Red pepper is the dried, ripened fruit pod from the Capsicum species' pungent (hot) varieties. In addition to Cayenne, red pepper also goes by other names, including chili pepper, chile pepper, hot pepper, and red chillies ${ }^{1}$. Pepper is one of the most important plants that have been used as medicine for a long time in different countries and civilizations ${ }^{2}$. Because modern medicines such as antibiotics that previously enjoyed almost comprehensive adequacy against pathogens weaken their effectiveness ${ }^{3}$.

The spread of resistant pathogens, manufactured medicines are one of the most severe problems that impede the success of treatments for diseases caused by germs. Since ancient times plant extracts and volatile oils have drawn attention as a source of natural products as they have shown their therapeutic power as an alternative for treating many infectious diseases ${ }^{4}$. The effect of medicinal plants on the growth of microorganisms may lie in one of its components ${ }^{5}$; it contains active substances, including (volatile oils, glycosides, saponins, tannins, alkaloids, lipids, carbohydrates, resins, and stearylates $^{6}$. Pepper has antimicrobial properties that are important for the human health of plants ${ }^{7}$ and antioxidant properties ${ }^{8,23}$. Studies have shown that they have anti-bacterial, antifungal, and antiviral properties ${ }^{9}$. Research in the use of plant extracts and their active components as anti-bacterial agents, as the inhibitory effect of the active substances in these plants, is dilute and easy. Bodies can interact with them; in addition to that, they contain many active substances that work together to treat the disease, so it was used for many pathological symptoms ${ }^{9}$. The World Health Organization (WHO) indicated that a large proportion of the world's population primarily uses folk medicine in health care and medicine ${ }^{10}$. It is worth noting that the world is now more inclined than before to treat herbs and medicinal plants after the results of the research have shown the effectiveness of treatment with them, and there has become a near-global race to register the most significant possible number of patents for the results of the research that is being conducted.

The present study aimed to isolate and diagnose different multiresistant Gram-positive and gram harmful bacteria and to study the effect of red pepper extracts on the isolated bacteria-the Comparison effect of watery and alcoholic pepper extract with several commonly used antibiotics.

\section{Materials and methods}

Sixty samples were collected from patients with various infections and pathological injuries from different areas of the body from Tikrit Teaching Hospital were placed directly after taking them in test tubes containing the sterile medium (Brain heart infusion broth), after which the tubes were transferred to the laboratory, incubated at $37^{\circ} \mathrm{C}$ for 24 hours in blood base agar and McConkey media.

\section{Bacterial isolates}

Seven bacterial species were isolated from different parts of human bodies, and they confirmed that they are pathogenic bacteria. Nutrient Agar base and MacConkey Agar were incubated at $37^{\circ} \mathrm{C}$ for 24 hours

\footnotetext{
Science College/ Tikrit University, Iraq.

${ }^{2}$ College of Medicine/ Tikrit University, Iraq.
} 


\section{Preparing plant extracts}

The aqueous extract was prepared by mixing 40 grams of dry red pepper with 160 milliliters of sterile distilled water. While the alcoholic extract, mix 40 grams of the dry plant model with 160 milliliters of ethyl alcohol at a concentration of $95 \%$ to prepare the alcoholic extract, stir the mixture with a shaker device, and leave the mixture in the refrigerator for 24 hours. For soaking. Filter using filter paper to get rid of unpowdered particles and fibers. After filtration, the extract is placed in the incubator at $40^{\circ} \mathrm{C}$ until all liquids are evaporated and the extract remains in Baker's base ${ }^{6,11}$.

\section{Sterilization of the alcoholic extract}

It was prepared by dissolving $1 \mathrm{~g}$ of the plant extract in $5 \mathrm{~cm}^{3}$, sterilizing the mixture at a temperature of $62^{\circ} \mathrm{C}$ for 15 minutes, thus obtaining the standard center of the alcoholic extract used to prepare the subsequent dilution ${ }^{10,12}$.

\section{Diffusion test method}

The methods included drilling a nutrient agar medium of equal dimensions with a diameter of $6 \mathrm{~mm}$ using the cork borer. $0.1 \mathrm{ml}$ of the bacterial leeches is spread on the surface of the medium, and then the pits are filled with the extractor solution, and the plates are then incubated at $37^{\circ} \mathrm{C}$ for 18 hours, then the extract's effectiveness is evaluated. Inhibition on bacteria by measuring the diameter of the inhibition circuit

\section{Antibiotic sensitivity test}

The method (Kirby Bauer) ${ }^{13}$ was followed to test the susceptibility of germs to the types of antibodies used prepared by the company (Bioanalyse) where (5-4) pure colonies of these germs were transferred to the medium of the nutritious broth and the bacterial cultures were immunized to a degree. $37 \mathrm{C}$ for a period of $(14-16)$ hours, then dilute the bacterial suspension with the physiological solution compared to the standard control tube, which is equivalent to 10 cells $/ \mathrm{cm}^{3}$, then transfer $0.1 \mathrm{~cm}$ of the bacterial suspension to the medium of neutron agar and by using a cotton swab spread on the surface of the plate using a cotton swab left the dishes at a degree. The room temperature was set for 30 minutes, then the antibiotic tablets were fixed and using sterile forceps, the dishes were preserved for (14-16) hours, then the area of growth inhibition was measured by one millimeter ${ }^{14}$, and then the results were recorded.

In this study, samples were taken from patients suffering from pathological injuries and different body areas according to the area of injury shown in Table (1).

\section{Diagnosis and identification}

The bacterial colonies growing on media (McConkey agar and nutrient agar media) were identified through microscopy, culture characteristics, and biochemical tests, which included tests (catalase, oxidase, indole, red methyl, vox-Proskauer, Simmons citrate, motility, urease, Klingler iron agar test).

As for the tests for bacteria of the genus Staphylococcus included (catalase test, clotting test, growth on mannitol salt agar, oxidase and urease).

\section{Results and discussion}

The alcoholic extract showed higher inhibitory efficacy than aqueous on the growth of isolates of multiple antibiotic-resistant bacteria.

The aqueous extract of the red pepper plant showed good inhibitory efficacy against the studied microbial species, as it had the highest inhibitory action against E. coli, with the average diameter of the inhibition circle diameter $16.5 \mathrm{~mm}$, and it is an excellent inhibitory when compared with the antibiotics Gentamicin and Nitrofurantoin as it showed good inhibitory efficacy against because this pepper contains a large number of fatty acids esters, amides, monoterpenes, diterpenes ${ }^{15}$. triterpenes, sesquiterpenes, and phytosterols were shown in Sharma et al. $^{16}$. It also exhibited significant antimicrobial activity against pathogenic microorganisms ${ }^{17}$. The bacteria $S$. aureus, $P$ aeruginosa, and Salmonella. Sp. The results were identical to the results of Araujo et $a{ }^{1 .}{ }^{18}$. The results in the current study disagree with Soetarno et al. ${ }^{19}$ how tested the antimicrobial property of pepper and found ethanol extracted pepper was more effective than aqueous extracted.

The extract did not show any inhibitory efficacy against the bacterium Proteus. sp, while the alcohol extract showed the inhibitory activity against the bacterium itself. From the rates of inhibition diameters, the bacterium was found most affected by the alcohol extract of the plant, which showed High

\begin{tabular}{|l|l|l|}
\hline Bacteria Type & isolation area & Type of infection \\
\hline S. aureus & Throat & Laryngitis \\
\hline Streptococcus spp & Gum & Gingivitis \\
\hline Salmonella spp & Intestinal & Food poisoning \\
\hline E. coli & Intestinal & Intensive inflammation \\
\hline Proteus spp & Urinary tract & Urinary tract inflammation \\
\hline P.aeruginosa & Intestinal & Intestinal diarrhea \\
\hline Klebsiella & Intestinal & Intestinal diarrhea \\
\hline
\end{tabular}

Table 1. Shows the areas of bacterial isolation and the disease state isolated from them. 


\begin{tabular}{|c|c|c|c|c|c|c|c|}
\hline $\begin{array}{l}\text { Extract } \\
\text { concentration } \\
\mathrm{Mg} / \mathrm{mm}\end{array}$ & E.coli & $\begin{array}{l}\text { Staph } \\
\text { aureus }\end{array}$ & $\begin{array}{l}\text { Streptococ } \\
\text { cus spp }\end{array}$ & $\begin{array}{l}\text { Ps. } \\
\text { Aeruginosa }\end{array}$ & $\begin{array}{l}\text { Kl. } \\
\text { Pneumonia }\end{array}$ & $\begin{array}{l}\text { Proteus } \\
\text { spp }\end{array}$ & $\begin{array}{l}\text { Salmonella } \\
\text { spp }\end{array}$ \\
\hline \multicolumn{8}{|c|}{ Aqueous extract } \\
\hline 200 & 16.5 & 12.5 & 11.5 & 12 & 9.2 & 0 & 11 \\
\hline 100 & 12 & 11 & 10.3 & 10.5 & 8.5 & 0 & 9.5 \\
\hline 50 & 9 & 9 & 8.7 & 9 & 0 & 0 & 7.5 \\
\hline 25 & $\mathbf{0}$ & 0 & 0 & $\mathbf{0}$ & 0 & 0 & 0 \\
\hline \multicolumn{8}{|c|}{ Alcoholic extract } \\
\hline 200 & 11 & 15 & 12 & 13.8 & 9.3 & 11 & 10.5 \\
\hline 100 & 8.5 & 12.5 & 10.3 & 10.3 & 7.2 & 9.5 & 7 \\
\hline 50 & 0 & 11 & 8 & 0 & 0 & 8 & $\mathbf{0}$ \\
\hline 25 & 0 & 9 & 6.4 & 0 & 0 & 0 & 0 \\
\hline
\end{tabular}

Table 2. The inhibitory efficacy of chilli pepper plants aqueous and alcoholic extract in bacterial species compared with the antibiotics used as a control sample (Diameter of the damping circuit measured in $\mathrm{mm}$ ).

\begin{tabular}{|l|c|c|c|c|c|c|c|}
\hline Antibiotic & \multicolumn{7}{|c|}{ Results Antibiotic Sensitivity } \\
\hline Gentamicin & $\mathbf{1 4}$ & $\mathbf{1 5}$ & $\mathbf{1 0}$ & $\mathbf{3 0}$ & $\mathbf{2 0}$ & $\mathbf{2 3}$ & $\mathbf{2 0}$ \\
\hline Ampicillin & $\mathbf{0}$ & $\mathbf{0}$ & $\mathbf{0}$ & $\mathbf{0}$ & $\mathbf{0}$ & $\mathbf{0}$ & $\mathbf{1 4}$ \\
\hline Ciprofloxacin & $\mathbf{0}$ & $\mathbf{0}$ & $\mathbf{0}$ & $\mathbf{0}$ & $\mathbf{0}$ & $\mathbf{0}$ & $\mathbf{1 7}$ \\
\hline Tetracycline & $\mathbf{1 3}$ & $\mathbf{8}$ & $\mathbf{7}$ & $\mathbf{0}$ & $\mathbf{1 5}$ & $\mathbf{1 0}$ & $\mathbf{8}$ \\
\hline Nitrofurantoin & $\mathbf{1 2}$ & $\mathbf{1 2}$ & $\mathbf{6}$ & $\mathbf{2 0}$ & $\mathbf{0}$ & $\mathbf{1 5}$ & $\mathbf{2 0}$ \\
\hline
\end{tabular}

Table 3. Antibiotics used to sensitivity test.

sensitivity inhibition when compared with the control sample tetracycline and nitrofurantoin as the results shown in the same Table showed that the alcoholic extract of the plant has inhibitory activity affecting the bacteria E.coli, P. aeruginosa, and Streptococcus sp. These results are similar to the results obtained by (20) Antimicrobial activity of ethanol extracts from different Capsicum against S. aureus, Saccharomyces was investigated by (14 and 21) and anti-bacterial

The activity of chili against Bacillus subtilis and E. coli was reported by De et al. ${ }^{22}$. The alcoholic extract of the red pepper plant was found to have inhibitory efficacy against many types of germs, and the Klebsiella sp bacterium was cleansed. The bacterial species was least affected by the aqueous and alcoholic extract of the plant; as the average diameter of the inhibition, the circuit was about $9.2 \mathrm{~mm}$ at a concentration of $200 \mathrm{mg} / \mathrm{cm}^{3}$ bitter, which the substance's inability can explain. The effective dissolved in water and alcohol to penetrate the biological envelope of the germ, as the reason for this may be attributed to its possession of medicine. The mucosal time (reduced) may give it an essential defensive factor that protects it from the inhibitory action of the active components of the extract $^{23}$. Many researchers demonstrated the effect of plant extracts on bacterial inhibition ${ }^{1,2,24}$. The use of various compounds to inhibit pathogenic bacteria has been discussed in previous studies, such as the direct influence of $\mathrm{Ag}$ and $\mathrm{TiO} 2$ nanoparticles on pathogenic bacteria such as P. mirabilis and Proteus vulgaris in a previous study ${ }^{25}$. However, several studies have discovered that applying physical forces therapy to pathogenic bacteria, such as Audible Sounds and Magnetic Fields, can help to reduce the resistance of $S$. aureus to infection ${ }^{26}$.

\section{Conclusiones}

The plant's aqueous and alcoholic red pepper extracts were effective against the tested bacterial isolates. The highest in- hibitory action of the plant's aqueous red pepper extract was against E.coli, while there was no inhibitory effect against the bacterium Proteus sp.

\section{Conflict of interest}

The author declares that there is no conflict of interest for this study.

\section{Referencias bibliográficas}

1. Al-Hadidy Y I, Yaseen S S, Saleh G M. The Inhibitory Effect of some Plant Extracts on some Pathogenic Bacteria. Tikrit Journal of Pure Science. 2019; 24 (1):62-69.

2. Ameya G, Aklilu A, Bisrat N, Nassir M \& Negash A . In Vitro antimicrobial activity of fermented spices and capsicum frutescens against multi drug resistance clinical isolate and standard reference bacteria. afr. j. cln. exper. microbiol. 2018;19 (1): 9-17.

3. Bacon K, Renee B, Cynthia D, Sean O, Andrew N, Robert W . Anti-bacterial activity of jalapeño pepper (Capsicum annuum var. annuum) extract fractions against select foodborne pathogens. Food Sci Nutr. 2017;5 (3):730-738.

4. Chouhan S, Sharma K and Guleria S. Antimicrobial Activity of Some Essential Oils-Present Status and Future Perspectives. JMedicines.2017; 4 (58) doi:10.3390/medicines4030058.

5. Parham S, Kharazi A, Bakhsheshi-Rad H, Nur H, Ismail A, Sharif S, Krishna S and Berto F. Antioxidant, Antimicrobial and Antiviral Properties of Herbal Materials. Antioxidants. 2020; 9(12): 1309; https://doi.org/10.3390/antiox9121309

6. Nayyef S H, Abed SM, Yaseen L Q . effect of aloe vera leaves gel and it's alcohol extraction on some bacteria isolated from human body . The Euphrates Journal of Agriculture Science .2016; 149-159.

7. Saleh B, Abdella O, Belay T. Medicinal uses and health benefits of chili pepper (Capsicum spp.): a review. MOJ Food Process Technol. 2018;6(4):325区328.

8. Burt S A .Essential oils: There anti-bacterial properties and potential applications in food : Review . International Journal of Food Microbiology.2004;94 (3):223-253. 
9. Zarringhalama M, Jalal Z, Mehdi S, Firouzeh S and Elaheh T. Inhibitory Effect of Black and Red Pepper and Thyme Extracts and Essential Oils on Enterohemorrhagic Escherichia coli and DNase Activity of Staphylococcus aureus. Iranian Journal of Pharmaceutical Research .2013; 12 (3): 363-369.

10. Nevry R, Kouassi K, Nanga Z, Koussémon M \& Loukou G . Antibacterial Activity of Two Bell Pepper Extracts:Capsicumannuum L. and Capsicumfrutescens . International Journal of Food Properties. 2013; 15( 5): 961-971.

11. Nurjanah S, Sudaryanto A , Widyasanti and Pratiwi. Anti-bacterial activity of Capsicum annuum L. oleoresin. International Society for Horticultural Science.2016;.23: 189-194.

12. Omolo A , Wong Z, Amanda K and David B. Antimicrobial Properties of Chili Peppers. J nfectious Diseases \& Therapy.2014; 2 ( 4): doi:10.4172/2332-0877.1000145.

13. Cruickshank R, Duguid J and Swain R. Medical Microbiology . 12th ed . London and New York. 1975; Churchill Livingstone.

14. Hadi H, Hasan R. Effect of plant extracts of Salvia officinalis $L$. and Costus speciosus $L$. in growth of some bacteria species isolated from urinary tract infections in Samarra city. Tikrit Journal of Pure Science.2020; 25 (1) :47-51.

15. Xiaomiao H , Huadan T and Yanping Z . Study on antimicrobial activities of ethanol extracts from different Capsicum cultivars. Agricultural Science \& Technology.2012; 13 (12): 2514-2517.

16. Sharma P. Fuloria S, Alam S, Sri M and Singh A. Chemical Composition and Antimicrobial Activity of Oleoresin of Capsicum annuum Fruits. Mindanao Journal of Science and Technology 2021; 19 (1) : 29-43.

17. Yihune E \& Yemata G. Antibacterial activity of medicinal plant extracts against Ralstonia solanacearum (Smith) that causes bacterial wilt in hot pepper (Capsicum annuum L.). Universidade Estadual de Maringá. 2019; 41. Doi: 10.4025/actascibiolsci. v41i1.45402

18. Araujo J, Carmona A , Dorantes L and Haernandezsanchez H. Effect of capsicum Extracts and Cinnamic acid on the growth of some important bacteria in dirty products . book series , food engeneering series, Springer New York.2008; 1STed
19. Soetarno S, Sukrasno E, Yulinah and Sylvia. Antimicrobial Activities of the Ethanol Extracts of Capsicum Fruits with Different Levels of Pungency, JMS.1997; 2 ( 2): 57 - 63.

20.Emmanuel-Ikpeme C, Henry P, \& Okiri O A. Comparative evaluation of the nutritional, phytochemical and microbiological quality of three pepper varieties. Journal of Food and Nutrition Sciences .2014; 2(3): 74-80.

21. f€uchtbauer S, Mousavi S, Bereswill S, and Heimesaat M . antimicrobial properties of capsaicin . European Journal of Microbiology and Immunology. 2021; 11 ( 1): 10-17.

22. De M, Krishna A and Banerjee A B, Antimicrobial screening of some Indian spices. J phytotherapy research . 1999; 13 (7): 616618.

23. Popelka P, Jevinová P, Šmejkal K. Antibacterial activity of Capsicum extract against selected strains of bacteria and micromycetes. Potravinarstvo Slovak Journal of Food Sciences.2017; 11 (1): 223-229 .

24. Lateef R H. Determiation the anti-bacterial activity of Punicagranatum Extract towards Streptococcus Pneumonia and Klebsella Pneumonia. Tikrit Journal of Pure Science .2019 ; 24 (2) :14-18.

25. Saleh TH, Hashim ST, Malik SN, AL-Rubaii BAL. Down-Regulation of full gene expression by Ag nanoparticles andTiO2 nanoparticles in pragmatic clinical isolates of Proteus mirabilis and Proteus vulgaris from urinary tract infection. Nano Biomed Eng.2019; 11(4):321-332.

26. Ali MAM and Al-Rubaii BAL. Study of the Effects of Audible Sounds and Magnetic Fields on Staphylococcus aureus Methicillin Resistance and mecA Gene Expression. Trop J Nat Prod Res. 2021; 5(5):825-830.

Received: 11 September 2021

Accepted: 23 October 2021 